\title{
Epidemiological determinants in outbreaks of bitter crab disease (Hematodinium sp.) in snow crabs Chionoecetes opilio from Conception Bay, Newfoundland, Canada
}

\author{
Jeffrey D. Shields ${ }^{1, *}$, David M. Taylor ${ }^{2}$, Paul G. O'Keefe ${ }^{2}$, Eugene Colbourne ${ }^{2}$, \\ Elaine Hynick ${ }^{2}$
}

${ }^{1}$ Virginia Institute of Marine Science, The College of William and Mary, Gloucester Point, Virginia 23062, USA

${ }^{2}$ Department of Fisheries and Oceans, CP5567, White Hills, St. John's, Newfoundland A1C 5X1, Canada

\begin{abstract}
Bitter crab disease (BCD) is caused by Hematodinium sp., an endoparasitic dinoflagellate. It lives within the hemocoeloms of snow crabs Chionoecetes opilio and Tanner crabs C. bairdi, making them unmarketable due to their bitter flavor. Two recent outbreaks of BCD have occurred in Conception Bay, Newfoundland, one from 1999 to 2000 and another from 2003 to 2005. In the earlier outbreak, prevalence was highest in juvenile and primiparous females and juvenile males. It was thought to be highest in these hosts because they molt more frequently than larger males and the disease is transmitted to newly molted crabs. In the 2003 to 2005 outbreak, the prevalence of BCD changed and was at its highest, $24 \%$ in trapped males and $13.5 \%$ in trawled males. This apparent shift in the dynamics of the infection between the earlier 1999 to 2000 and later 2003 to 2005 outbreaks was highly correlated with 2 factors: an increase in bottom temperatures, associated with the recent climatic warming trend in the Northwest Atlantic, and an increase in molting activity of the snow crabs due presumably to the temperature increase within Conception Bay. That is, rising temperatures occurring from 2003 to 2005 likely stimulated molting activity in snow crabs, which led to an increase in susceptible hosts in the population. Given the positive correlation between increased bottom temperature, increased molting activity, and the latest outbreak of $\mathrm{BCD}$, we predict that further trends in climatic warming will enhance transmission, spreading the parasite into additional fishing areas.
\end{abstract}

KEY WORDS: Ecology $\cdot$ Molting $\cdot$ Dinoflagellate $\cdot$ Temperature $\cdot$ Global warming $\cdot$ Climatic variation Epidemic $\cdot$ Epidemiology

\section{INTRODUCTION}

Bitter crab disease $(\mathrm{BCD})$, or bitter crab syndrome (BCS), is a fatal condition caused by the endoparasitic dinoflagellate Hematodinium sp. Infections occur in Tanner crabs Chionoecetes bairdi, snow crabs C. opilio (Meyers et al. 1987, 1990, 1996), and grooved Tanner crabs C. tanneri (Bower et al. 2003) off the northwest coast of North America. The disease was first reported in snow crabs $C$. opilio from eastern Canada (Conception Bay, Newfoundland) in 1990 (Taylor \& Khan 1995). At that time the disease was rare, with a very low prevalence $(0.037 \%)$. Unfortunately, it spread rapidly in the northeastern bays of Newfoundland, with prevalences rising in the late 1990s (Pestal et al. 2003), leading to an outbreak in Bonavista Bay in 1999 and in Conception Bay in 1999 and 2000 (Shields et al. 2005). The rapid spread of the disease is thought to be due to hydrographic features, which include shallow sills at the mouth of each bay that retain the transmissive stages in restricted areas (Meyers et al. 1987, Shields 1994, Dawe 2002, Shields et al. 2005). Off Newfoundland, BCD infections occur mostly in crabs from the large northeastern bays, but it also infects those from 
offshore regions, where its prevalence is much lower (Dawe 2002). It is not clear whether the same or similar species of Hematodinium occurs in Tanner crabs from northwestern North America and in snow crabs from northwestern and northeastern North America.

Infections of Hematodinium spp. are known to be fatal in virtually every infected host species (for review, see Stentiford \& Shields 2005). Mortality studies of Tanner crabs (Meyer et al. 1987, Love et al. 1993) and snow crabs (Shields et al. 2005) indicate that chronically infected crabs die over 100 or more days. Severe losses have occurred in several fisheries. However, most outbreaks in snow crabs are masked by the nature of the industry, which is trap-based, prosecuted during the spring and early summer and focuses on large, legal-sized males, which often have low prevalences of infection. Females and under-sized juvenile males, which normally have higher prevalences, are not retained in commercial traps due to mesh selection (Pestal et al. 2003, Shields et al. 2005). The bitter flavor that the disease imparts to infected snow and Tanner crabs results in a direct loss to their fisheries (Meyers et al. 1987, Eaton et al. 1991), where a single infected crab can ruin an entire batch of sections during bulk processing (D. M. Taylor pers. obs.). However, the obvious changes in shell color and bitter flavor may take several months to develop (Love et al. 1993, Pestal et al. 2003, Shields et al. 2005), leading to an under-reporting of the prevalence of BCD in species of Chionoecetes by commercial fishers and at-sea biological observers.

Transmission of BCD in snow crabs is associated with host molting. In snow crabs, $>98 \%$ of infections occurs in recently molted crabs, with virtually no infections in crabs that have not molted for a year or more (Shields et al. 2005). In the 1999 to 2000 outbreak, females and juvenile, small-clawed males had significantly higher prevalences of $\mathrm{BCD}$, and this was thought to be due to smaller animals having a higher molting frequency than larger, small-clawed males entering the fishery (Pestal et al. 2003, Shields et al. 2005). Males have 2 allometric morphotypes that are related to maturity: the small-clawed, often immature form, which molts relatively frequently, and the large-clawed mature form, which molts infrequently, if ever (Dawe et al. 1991). The former are often smaller and are largely prepubescent and pubescent juveniles, but occasionally they are sexually mature (Ennis et al. 1988, 1990, Dawe et al. 1991). Snow crabs can skip molting in a year if temperatures are low (e.g. $-1.3^{\circ} \mathrm{C}_{i}$ Taylor et al. 1993) or if they are not metabolically able (Benhalima et al. 1998, Hébert et al. 2002). Egg laying and the duration of egg incubation are annual or semiannual in females depending upon temperature (Saint Marie 1993, Comeau et al. 1999). The minimum legal size limit for males is $95 \mathrm{~mm}$ carapace width (CW), with the fishery emphasizing the higher grade value of the large-clawed males (>102 mm CW).

Since 1997, the presence of BCD has been incorporated in a qualitative way into assessments of the biomass of snow crabs for the fishery (DFO 2006a). The data from these assessments has led to an increased understanding of the biology of Hematodinium infections (e.g. Taylor \& Khan 1995, Dawe 2002, Pestal et al. 2003, Shields et al. 2005). Earlier we documented an outbreak of BCD in Bonavista and Conception bays from 1999 to 2000 (Shields et al. 2005). Here, we report on a new epidemic in Conception Bay that began in 2003 and increased in severity through 2005. The latest outbreak was different from the earlier outbreak in that prevalence was highest in large male crabs rather than in females and juvenile males. Therefore, the objectives were (1) to document the extent of the latest outbreak of BCD in snow crabs from Conception Bay, (2) to re-assess the biotic factors associated with the distribution and prevalence of the disease, and (3) to determine the underlying causes for the change in the dynamics of Hematodinium infections.

\section{MATERIALS AND METHODS}

Conception Bay. Conception Bay is a partially enclosed embayment with diverse bottom types ranging from sand and gravel at the mouth to thick mud in the inner deep basin (Fig. 1). Commercial crab fishing is conducted from 130 to $250 \mathrm{~m}$, where bottom temperatures normally range from -1.3 to $0.0^{\circ} \mathrm{C}$. The bay has a mean clockwise surface gyre, but near-bottom currents are weak, with a slow outflow during the fall and winter (DeYoung \& Sanderson 1995). The residence time of water in the bay has been calculated as $42 \mathrm{~d}$ (DeYoung \& Sanderson 1995). Conception Bay was sampled for snow crabs Chionoecetes opilio in September or October months, from 1997 to the present. A randomly stratified sampling program was used as described in Pestal et al. (2003). Crabs were captured with either a modified shrimp trawl or a fleet of traps with different mesh sizes (primarily 2.5, 13.3, or $14 \mathrm{~cm}$ ). Details of the trawling and trapping are given in Pestal et al. (2003) and Shields et al. (2005). Note that trawls represent a more unbiased sampling method compared to traps. Additional data on water temperature, salinity, and depth in Conception Bay were obtained by using CTDs from a series of annual multi-species surveys conducted by personnel from Department of Fisheries and Oceans, Canada.

Data were taken on crab sex, carapace width, claw height (to separate small- and large-claw males), shell condition (see below), maturity status (for females) and macroscopic signs of BCD. Maturity status for ran- 


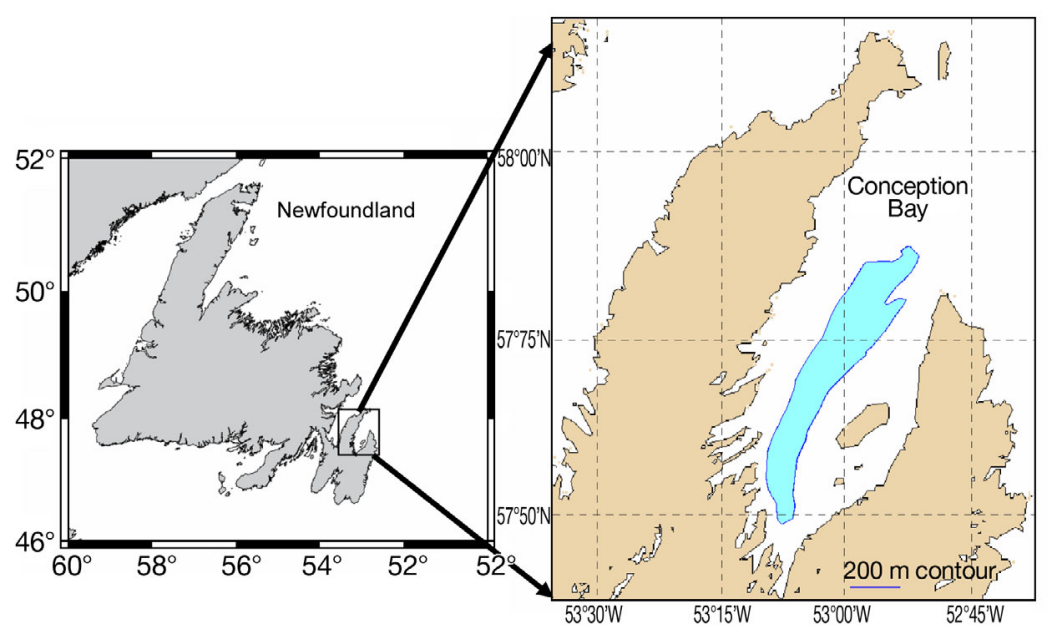

Fig. 1. Conception Bay, Newfoundland, with the $200 \mathrm{~m}$ depth contour

ratio, where the odds are a quotient of the probability of an event occurring divided by the probability that it does not occur (Thrusfield 1995). An odds ratio significantly $>1.0$ indicated that the odds of a crab being infected with BCD was a positive function of the independent variable. An odds ratio significantly $<1.0$ indicated a strong negative function with the independent variable. The prevalence ratio is the prevalence of an infection occurring in one group divided by the prevalence of an infection in another group (Thrusfield 1995). Prevalence is the number of infected crabs divided by the total number sampled, expressed as a percentage. Size classes comprised $5 \mathrm{~mm}$ increments from the beginning of the class size (i.e. $90 \mathrm{~mm}$

domly selected male crabs was determined using the formula $F=0.0806 \times \mathrm{CW}^{1.999}$, where if $F<$ claw height/10, the crabs were large clawed and if $F \geq$ claw height/10, then crabs were small clawed (Comeau \& Conan 1992). Shell condition was used as a proxy for molt stage and was scored as in Taylor et al. (1989), where Shell Condition 1 represented individuals that were soft, having molted within the last few months; Shell Condition 2 represented individuals with hard new shells, having molted within the last year; and Shell Condition 3 represented individuals with hard, old shells, not having molted within 2 yr. Later, an additional category was added as Shell Condition 6, represented by animals with hard, old shells intermediate to Shell Conditions 2 and 3. Crabs with BCD were diagnosed macroscopically by the distinct color change to the carapace of infected crabs (see Fig. 1 in Pestal et al. 2003). After 1998, crabs with suspected infections had their carapaces removed and their hearts were examined visually. White, opaque, or cloudy hearts were indicative of BCD, whereas uninfected crabs had beige, translucent hearts; this was verified histologically (100\% specificity; see Shields et al. 2005).

Statistical analysis. Logistic regression, linear regression, ANOVA and chi-square were used to analyze possible differences in host and environmental factors in relation to infection. All statistics were done with SYSTAT 10.0 (Wilkinson 1997). Logistic regression was used to model the effects of biotic variables on the probability of a crab being infected with BCD. The likelihood ratio test (LR test) was used to determine differences between full and nested logistic models. The odds ratio was calculated in the logistic regression models. The odds ratio is the comparison of 2 odds as a class includes 90 to $94 \mathrm{~mm}$ crabs). Two temporal periods, 1997 to 2002 and 2003 to 2005, were identified based on patterns in the prevalence of male crabs. These 2 periods were treated as a categorical variable for grouped analyses.

\section{RESULTS}

\section{Temporal pattern of disease}

Over the 9 yr period of the study, 99833 snow crabs Chionoecetes opilio from Conception Bay were visually examined for overt infections of BCD. Of these, 72486 crabs were caught in traps and 27347 were caught in trawls. In 2001, the trawl specimens were inadvertently collected with different footgear than that used normally. The trawl data for 2001 were, therefore, excluded from the analysis due to poor sample sizes and significant sample bias. However, the trap data for that year were not affected. Further, the temperature data for trawls in 2000 and 2001 were taken from their paired trap stations. For trawls, 22129 males were captured, of which 5841 were categorized as large clawed and 12329 were categorized as small clawed. For traps, 71334 males were captured, of which 21293 were categorized as large clawed and 9500 crabs were categorized small clawed. Prevalence and other variables did not differ significantly between the reduced and complete data sets based on male claw size.

The prevalence of infection of Hematodinium sp. varied markedly between years in Conception Bay (Fig. 2). In 1999, prevalence values were 9.5 and $2.8 \%$ in females and males from trawls, respectively. In 2000 , 

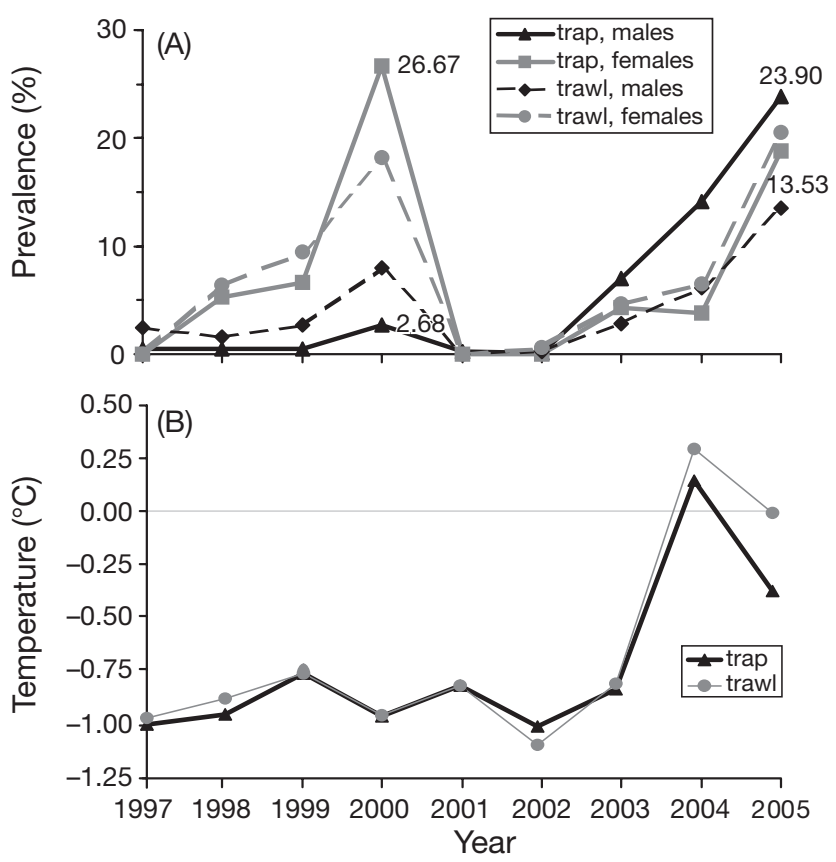

Fig. 2. (A) Annual prevalences of bitter crab disease (BCD) in trap- and trawl-caught Chionecetes opilio by sex. (B) Annual mean fall temperatures for trawls and traps. SD for temperature were all $<0.20$. Numbers are values for prevalences during epidemics

prevalence values were higher, 26.7 and $18.2 \%$ in females collected by traps and trawls, respectively. In males, prevalence values were 2.7 and $8.0 \%$ in traps and trawls, respectively. From 2001 and 2002, the trap data indicated that the epidemic in Conception Bay had subsided, but, in 2003, prevalence values had risen to 7.0 and $2.9 \%$ in trapped and trawled male crabs and 7.0 and $4.7 \%$ in trapped and trawled female crabs, respectively. By 2005, prevalence was at an alltime high for trapped and trawled male crabs, with 23.9 and $13.5 \%$, respectively, bearing infections. Infections in trapped females were also high at this time, with a prevalence of $18.8 \%$.

The disease dynamics shifted after 2002 with higher prevalence in legal-sized male crabs. Prior to 2003, BCD in trawled crabs was most prevalent in sublegal, small-clawed males (Fig. 3) and females (Fig. 2). From 2003 to 2005, the prevalence of the disease shifted such that legal large- and small-clawed males had much higher prevalence values than in previous years. In 2005, the prevalence in legal large-clawed males was $34.6 \%$ and that in legal small-clawed males was $14.9 \%$. This shift in the dynamics of infections was even more evident when the size-frequency distribution was analyzed in relation to prevalence within each size class. Prevalence in females peaked at $40 \mathrm{~mm} \mathrm{CW}$ in both temporal periods, 1997 to 2002 and 2003 to 2005 (Fig. 4). The size frequencies were significantly
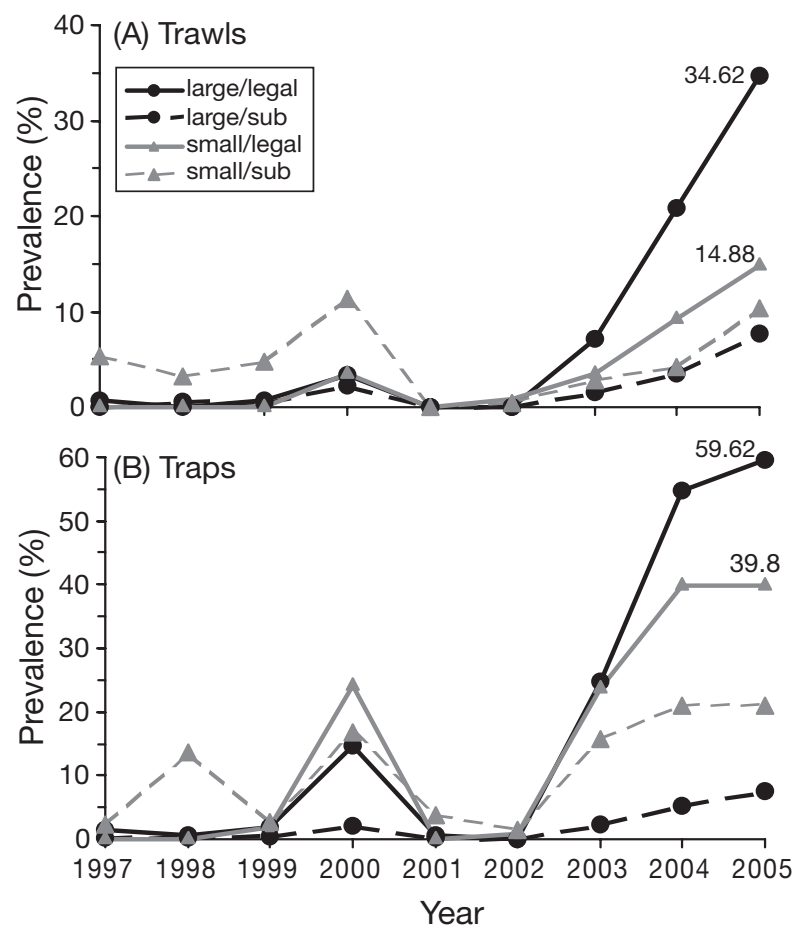

Fig. 3. Chionoecetes opilio. Annual prevalence of bitter crab disease (BCD) in legal and sublegal males by claw morphotype for (A) trawls and (B) traps. Numbers are prevalences; $y$-axes have different scales
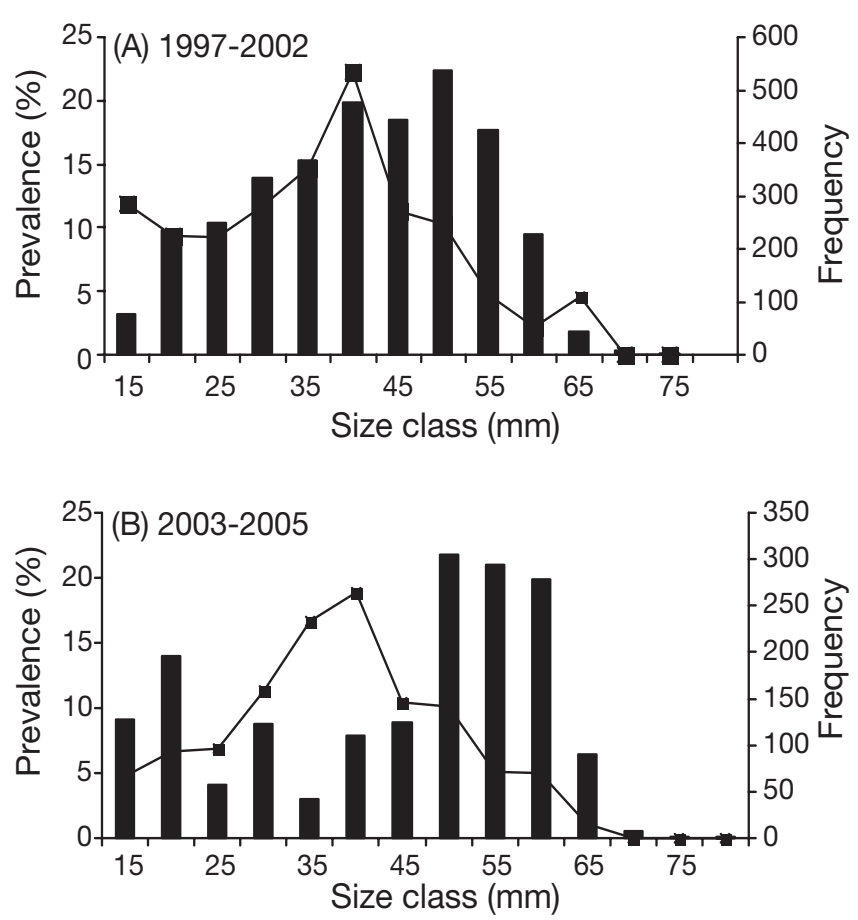

Fig. 4. Chionoecetes opilio. Size-frequency distribution and prevalence of bitter crab disease (BCD) by size class $(5 \mathrm{~mm}$ classes) for female crabs caught in trawls from (A) 1997 to 2002 or (B) 2003 to 2005. Solid bars: number of crabs in size class; solid line: prevalence (\%) of BCD. Prevalence remains similar in both periods; $y$-axes have different scales 
different between years because of the smaller numbers of females caught in the 30 to $45 \mathrm{~mm}$ CW classes in the 2003 to 2005 period (chi-square $=528.1, \mathrm{df}=13$, $\mathrm{p}<0.001$ ). Prevalence values in males were bimodal in the 2003 to 2005 period, with a peak at $35 \mathrm{~mm} \mathrm{CW}$ and a peak building in sizes $>85$ to $130 \mathrm{~mm} \mathrm{CW}$ (Fig. 5). The size frequencies were significantly different between years because of the smaller numbers of males in the 30 to $45 \mathrm{~mm} \mathrm{CW}$ classes in the 2003 to 2005 period (chi-square $=676.3, \mathrm{df}=25, \mathrm{p}<0.001$ ). Crabs of legal size also showed different proportions in claw morphotypes between periods. In 1997 to 2002, large-clawed males made up 94.4 and $84.2 \%$ of the legal-sized catch in traps and trawls, respectively. In 2003 to 2005, large-clawed males made up 54.6 and $63.9 \%$ of the legal catch in traps and trawls, respectively.

Crab density was not associated with the outbreaks. Density, as catch per unit effort (CPUE, as mean number of male crabs per pot), was variable among years for male crabs caught in traps (Fig. 6). However, CPUE in 2004 and 2005 showed a downward trend, with CPUE in 2005 being significantly lower than in other years, except for 2004, which was significantly lower than the years with the highest CPUE (ANOVA, $\mathrm{df}=8$, $231, \mathrm{p}<0.001, F=6.7209$, Tukey's honestly significant
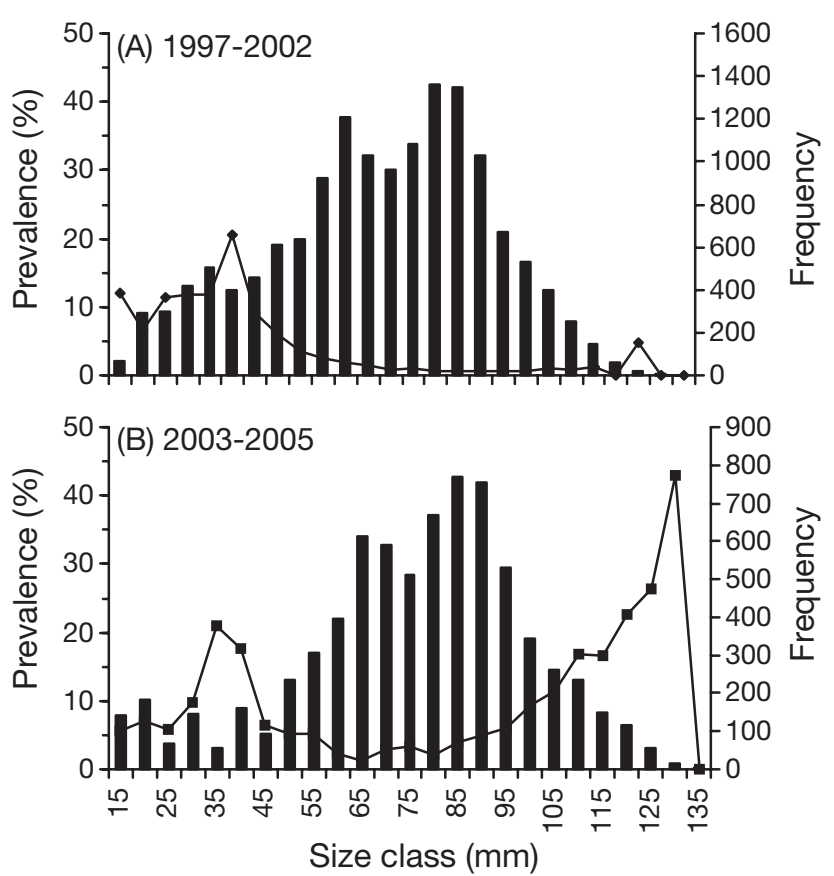

Fig. 5. Chionoecetes opilio. Size-frequency distributions and prevalence of bitter crab disease (BCD) by $5 \mathrm{~mm}$ size classes for male crabs caught in trawls from (A) 1997 to 2002 or (B) 2003 to 2005. Solid bars: number of crabs in size class; solid line: prevalence (\%) of BCD. Note the shift in prevalence in the larger size classes after 2003. Frequency axes varies by period
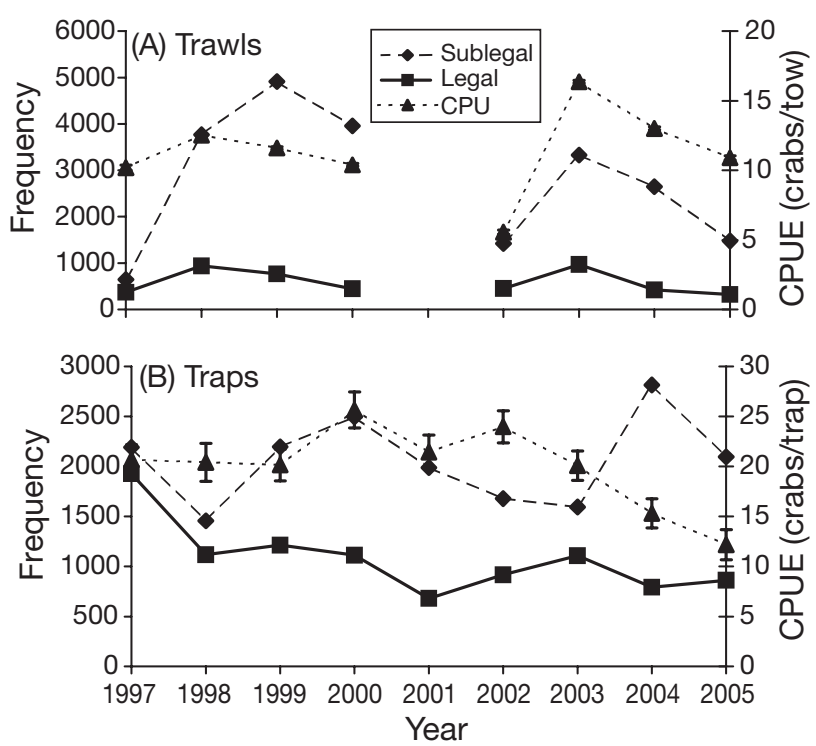

Fig. 6. Chionoecetes opilio. Abundance (frequency) and catch per unit effort (CPUE; crabs per tow [trawl] or pot [trap]) over time for male crabs from (A) trawls and (B) traps. $y$-axes differ between methods of capture. SE for CPUEs in trawls were very small (not shown)

difference [HSD] test). For trawl-caught crabs, CPUE was calculated as the mean number of crabs per tow. CPUE for trawl-caught crabs was also variable among years. CPUE in 2004 and 2005 showed a downward trend, with CPUE in both years being significantly lower than in years with high CPUE (1998 to 2003, excluding 2001) (ANOVA, df $=8,158, \mathrm{p}<0.001, F=$ 8.9346). That is, high densities of crabs were not associated with increased prevalence of BCD. As expected, crab abundance (raw frequencies of crabs) showed a similar pattern to CPUE. In traps and trawls there were significantly more sublegal crabs in 2004 than in other years, but there was no association with prevalence.

\section{Temporal patterns in molting}

Shell condition, as a proxy for molting activity, showed 2 distinct temporal patterns in both the trapped and trawled male crabs. Prior to 2001, largeclawed males in Shell Condition 2 (hard, new shell, molted within the preceding year) made up a small proportion (generally $<20 \%$ ) of the subpopulation of large-clawed crabs (Fig. 7). However, from 2002 to 2005 , the proportion of small-clawed males moulting into large-clawed animals (large-clawed Shell Condition 2) increased markedly to $>75 \%$, indicating an increase in molting activity in this subpopulation of crabs. Interestingly, from 1997 to 2005, a large proportion of small-clawed crabs were in Shell Condition 2 (70 to $80 \%$ ), with the exception of 2001 , when little 

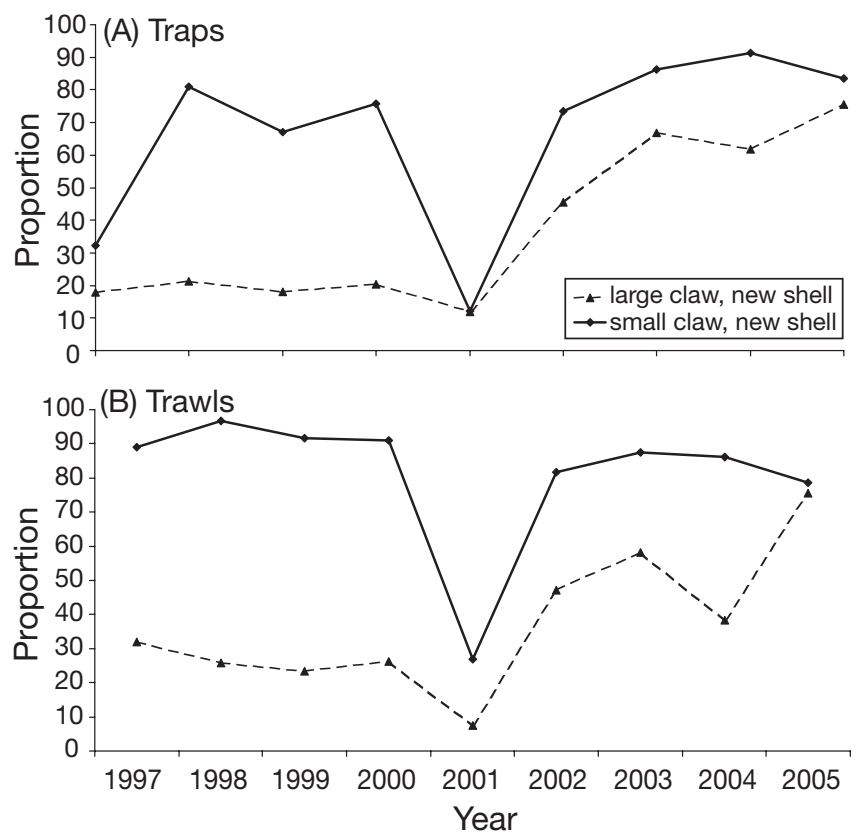

Fig. 7. Chionoecetes opilio. Proportion (\%) of large-clawed male crabs in Shell Condition 2 compared to large-clawed male crabs in other shell conditions over time plotted with similar data for small-clawed male crabs in (A) traps and (B) trawls. Other shell conditions (1,3 and 6) are not shown as they were considerably smaller in proportion. Trawl data for 2001 were included because the collection gear may not have biased shell type

molting activity occurred in either small- or largeclawed males. This pattern was similar in both trapped and trawled animals.

The prevalence of infection differed significantly among shell conditions. From 1997 to 2002, 98.4\% of the infections occurred in crabs in Shell Condition 2, with $1.4 \%$ in crabs in Shell Condition 6, and $0.1 \%$ in crabs in Shell Conditions 1 and 3. From 2003 to 2005, $91.9 \%$ of the infections occurred in crabs in Shell Condition 2, with $7.9 \%$ in crabs in Shell Condition 6, and $0.2 \%$ in crabs in Shell Condition 1. Further, the size of infected crabs varied between shell conditions. For 1997 to 2002, the mean size of trawled male crabs in Shell Condition 6 with BCD (intermediate, not molted within preceding year) was $87.1 \pm 0.4(\mathrm{SE}) \mathrm{mm}$ CW, which was significantly larger than that for infected crabs in Shell Condition $2(48.6 \pm 0.9 \mathrm{~mm} \mathrm{CW})$, but there were no differences in sizes in 2003 to 2005 (2-way ANOVA, condition, temporal period, df $=1$, 4089, $\mathrm{p}<0.001)$.

\section{Temperature and BCD}

Bottom temperature was significantly higher in Conception Bay during 2004 and 2005 (Fig. 1) compared to other years (ANOVA, df =6, 9183, $F=9899, \mathrm{p}<0.001$, Tukey's HSD, $\mathrm{p}<0.001)$. Mean bottom temperatures for the fall periods were positively correlated with prevalence of BCD in trawled crabs (linear regression, prevalence $=3.4189 \times$ temperature -0.9117 , $\mathrm{df}=8$, correlation coefficient $=0.7440, p=0.0215$ ), but the 2004 and 2005 data points were clearly statistical outliers with heteroscedastic residuals, weakening the relationship. However, data from the multi-species trawl surveys collected in other months indicated that monthly temperatures were higher than historic means in Conception Bay in the 2003 to 2005 period compared to 1997-2002 (Fig. 8). Further, spring and early summer temperatures were 0.5 to $1.0^{\circ} \mathrm{C}$ higher in the 2003 to 2005 period. The overall mean temperature from 1997 to 2002 was $-0.88+0.15$ (SD) ( $\mathrm{n}=158$ ), which was significantly different (t-test, p < 0.001) from that for 2003 to 2005 , which was $-0.30+0.41$ (SD) ( $\mathrm{n}=114)$.

The relationships between fall bottom temperature, shell condition, maturity, and BCD were analyzed using data on trawled males. This capture method was considered unbiased with respect to crab size due to the very small-meshed liner fitted into the cod end of the trawl. The full model, which included all of the interaction terms, was not significantly different from the final model (LR test, chi-square $=1.34$, p > 0.50); therefore, the final model was used to examine the associations between the independent variables and prevalence (Table 1). Maturity (small- vs. largeclawed males), temporal period (1997 to 2002 vs. 2003 to 2005), and carapace width were significant main factors in the model; they also showed significant interactions between variables. Temperature was not significant as a main factor, yet it had significant interactions with $\mathrm{CW}$, shell condition, and temporal

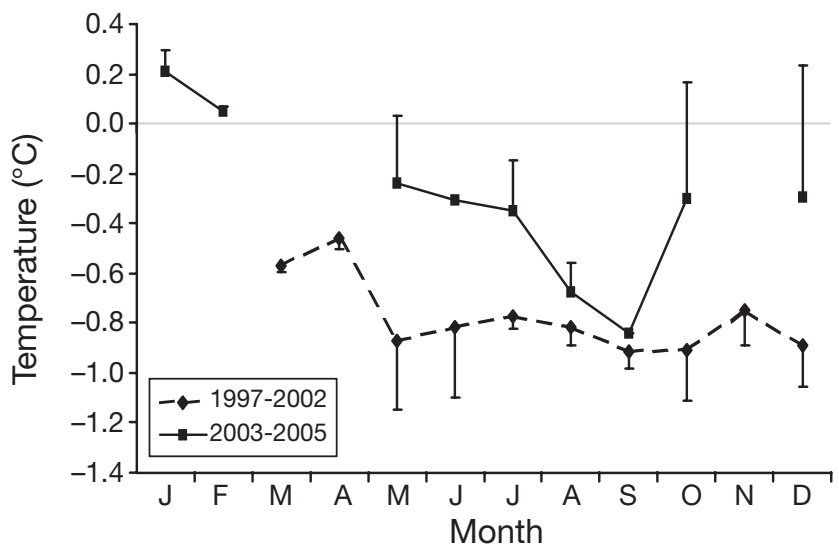

Fig. 8. Mean monthly bottom (>200 m) temperatures (only one side of the standard deviation is shown for clarity) for 1997 to 2002 (dashed line) and 2003 to 2005 (solid line) for Conception Bay 
Table 1. Chionoecetes opilio. Estimates for the final logistic regression model testing the effects of temperature, shell condition (Condition 2 vs. all others), and maturity (small- vs. large-clawed male) on the probability of infection by bitter crab disease (BCD) for male snow crabs trawled from Conception Bay, 1997 to 2005. Years were grouped into 2 temporal periods (1997 to 2002, 2003 to 2005), because the model failed to converge with individual years. Temp: temperature, continuous variable; Width: carapace width, continuous variable; Shell: shell condition, categorical; Mature: claw morphotype, categorical. The estimates and odds ratios for Shell are for Shell Condition 2 (odds $=1.0$ ) compared to other shell conditions. The estimates and odds ratios for Mature are for largeclawed males (odds $=1.0$ ) compared to small-clawed males. The estimates and odds ratios for Year are for 2003-2005 (odds $=1.0$ ) compared to 1997-2002

\begin{tabular}{|c|c|c|c|c|}
\hline Parameter & Coefficient & $\mathrm{SE}$ & $t$ & $\mathrm{p}$ \\
\hline Constant & -2.46 & 0.35 & -7.08 & 0.00 \\
\hline Shell & 0.63 & 0.25 & 2.58 & 0.01 \\
\hline Mature & -4.95 & 0.68 & -7.32 & 0.00 \\
\hline Year & -2.44 & 0.68 & -3.56 & 0.00 \\
\hline Temp & -0.27 & 0.52 & -0.51 & 0.61 \\
\hline Width & -0.01 & 0.00 & -1.95 & 0.05 \\
\hline Width $\times$ Temp & 0.01 & 0.00 & 2.17 & 0.03 \\
\hline Width $\times$ Mature & 0.05 & 0.01 & 7.30 & 0.00 \\
\hline Width $\times$ Year & -0.02 & 0.00 & -5.28 & 0.00 \\
\hline Temp $\times$ Shell & 1.17 & 0.39 & 3.02 & 0.00 \\
\hline Temp $\times$ Year & -3.14 & 0.45 & -7.01 & 0.00 \\
\hline Shell $\times$ Year & 1.63 & 0.46 & 3.55 & 0.00 \\
\hline Shell $\times$ Mature & 1.38 & 0.34 & 4.05 & 0.00 \\
\hline \multirow[t]{2}{*}{ Parameter } & \multirow[t]{2}{*}{ Odds ratio } & \multicolumn{3}{|c|}{$-95.0 \% \mathrm{CI} \longrightarrow$} \\
\hline & & \multicolumn{2}{|c|}{ Upper } & Lower \\
\hline Shell & 1.88 & \multicolumn{2}{|l|}{3.05} & 1.17 \\
\hline Mature & 0.01 & \multicolumn{2}{|l|}{0.03} & 0.00 \\
\hline Year & 0.09 & \multicolumn{2}{|l|}{0.33} & 0.02 \\
\hline Temp & 0.77 & \multicolumn{2}{|l|}{2.11} & $\begin{array}{l}0.02 \\
0.28\end{array}$ \\
\hline Width & 0.99 & \multicolumn{2}{|l|}{1.00} & 0.99 \\
\hline Width $\times$ Temp & 1.01 & \multicolumn{2}{|l|}{1.02} & 1.00 \\
\hline Width $\times$ Mature & 1.05 & \multicolumn{2}{|l|}{1.06} & 1.04 \\
\hline Width $\times$ Year & 0.98 & \multicolumn{2}{|l|}{0.99} & 0.97 \\
\hline Temp $\times$ Shell & 3.23 & \multicolumn{2}{|l|}{6.91} & 1.51 \\
\hline Temp $\times$ Year & 0.04 & \multicolumn{2}{|l|}{0.10} & 0.02 \\
\hline Shell × Year & 5.10 & \multicolumn{2}{|l|}{12.55} & 2.07 \\
\hline Shell $\times$ Mature & 3.96 & \multicolumn{2}{|l|}{7.71} & 2.03 \\
\hline \multicolumn{5}{|c|}{$\begin{array}{l}\text { Log likelihood }(\mathrm{LL}):-2160.58, \mathrm{LL} \text { of constants only model } \\
=\mathrm{LL}(0)=-2531.81,2 \times[\mathrm{LL}(\mathrm{N})-\mathrm{LL}(0)]=742.46 \text { with } 12 \mathrm{df} \\
\text { chi-square p-value }=0.00, \mathrm{McF} \text { adden's rho-squared } \\
0.15 ; \mathrm{n}=672 \text { infected crabs, } 10364 \text { uninfected crabs }\end{array}$} \\
\hline
\end{tabular}

period, but not with maturity. Temperature had the largest significant interaction term with temporal period (slope $=-3.14$, odds $=0.04$ ) followed by its large positive interaction with shell condition (slope = 1.17 , odds $=3.23$ ). Shell condition also was not significant as a main factor, but it had significant interactions with maturity, temporal period, and temperature. The significantly strong interactions between shell condition and maturity and between shell condition and temperature are also indications of increased molting activity occurring in the snow crab population in the 2003 to 2005 period. In the logistic regression model, the probability of infection was clearly associated with temperature when shell condition and carapace width were held constant, primarily because of the changes in the interaction terms (Fig. 9). Therefore, temperature was a significant positive factor in BCD infections in 2003 to 2005, but a weak negative or non-significant factor in the 1997 to 2002 period, primarily because temperature was relatively constant in the earlier period.

The relationships between fall bottom temperature, shell condition, maturity, and BCD were also analyzed using data on trawled females. The full model, which included all of the interaction terms, was not significantly different from the final model (LR test, chisquare $=3.20, \mathrm{df}=8, \mathrm{p}>0.50$ ); therefore, the final model was used to examine the associations between the independent variables and prevalence (Table 2). All of the variables except maturity (immature vs. mature) were significant main factors in the model, but only width versus maturity and temperature versus temporal period had significant interactions. Shell condition, maturity, temporal period, and the interaction between temperature and temporal period all had large slopes, indicating strong positive or negative associations with $\mathrm{BCD}$. Unlike in males, temperature did not have a significant interaction with shell condition or maturity for the females, nor did shell condition interact significantly with maturity. There was no evidence that females had increased molting activity in the 2003 to 2005 period. However, in the logistic regression model, the probability of infection was negatively associated with temperature between 1997 and 2002 , but positively associated with temperature in the 2003 to 2005 period (Fig. 10).

\section{Probabilities of infection and risk factors}

The probability of infection with BCD differed significantly between male and female crabs for both periods, 1997 to 2002 and 2003 to 2005. Therefore, logistic regression models testing the effects of carapace width and maturity stage on the probability of infection were fit separately for male and female crabs (Tables $1 \& 2$ ). Probabilities of infection for small- and large-clawed males in relation to width showed marked differences between periods. When temperature was held constant at $0^{\circ} \mathrm{C}$ with Shell Condition 2, the slope of the relationship between probability of infection and carapace width changed markedly for large-clawed males between temporal periods (Fig. 11). The slope did not change for small- 

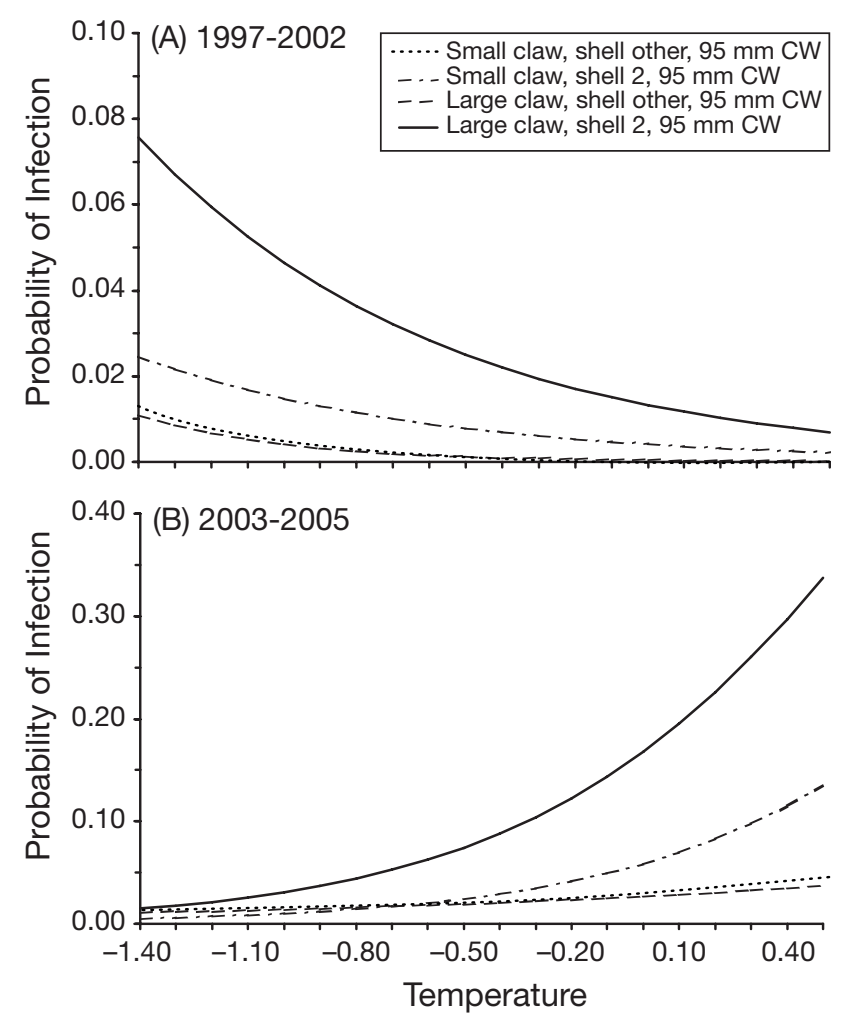

Fig. 9. Chionoecetes opilio. Estimated probabilities of infection with bitter crab disease (BCD) in relation to temperature for male snow crabs trawled from Conception Bay over 2 temporal periods: (A) 1997 to 2002 and (B) 2003 to 2005, with carapace width (95 mm CW) and Shell Condition 2 (shell 2) held constant. Regression model and equations are given in Table 1. Different molt conditions (Shell Condition 2 vs. other shell conditions) and maturity (immature vs. mature) have widely different probabilities of infection in the 2 temporal periods. Note change in scale of $y$-axes between periods

clawed males between periods, but the probability of infection was significantly greater in the 2003 to 2005 period. Therefore, both small- and large-clawed males had significant changes in their probabilities of infection after 2003 compared with those prior to 2003. In contrast, the probabilities of infection for immature and mature females did not differ in the signs of their slopes between periods, but the probabilities of infection were significantly greater for immature females in the 2003 to 2005 period compared to individuals in the other groups (Fig. 11).

Several host factors were analyzed separately to determine prevalence ratios (as a proxy for the odds ratios in cross-sectional studies; Table 3). Using this simplified analytical method, the shift in the dynamics of BCD infections was obvious in the prevalence ratios between males and females between temporal periods. The ratios changed significantly for large-clawed males, legal-sized crabs (largely comprised of large-
Table 2. Chionoecetes opilio. Estimates for the final logistic regression model testing the effects of temperature, shell condition (Condition 2 vs. all others), and maturity on the probability of infection by bitter crab disease (BCD) for female snow crabs trawled from Conception Bay, 1997 to 2005. Years were grouped into 2 temporal periods (1997 to 2002, 2003 to 2005), because the model failed to converge with individual years. Temp: temperature, continuous variable; Width: carapace width, continuous variable; Shell: shell condition, categorical; Mature: maturity status, categorical. Estimates and odds ratios for Shell are for Shell Condition 2 (odds = 1.0) compared to other shell conditions. Estimates and odds ratios for Mature are for mature females (odds $=1.0$ ) compared to immature females. Estimates and odds ratios for Year are for 2003-2005 (odds $=1.0$ ) compared to 1997-2002

\begin{tabular}{|c|c|c|c|c|}
\hline Parameter & Coefficient & SE & $t$ & $\mathrm{p}$ \\
\hline Constant & -4.97 & 0.67 & -7.44 & 0.00 \\
\hline Shell & 2.27 & 0.61 & 3.72 & 0.00 \\
\hline Mature & 1.95 & 1.66 & 1.17 & 0.24 \\
\hline Year & -1.67 & 0.62 & -2.69 & 0.01 \\
\hline Temp & 0.98 & 0.23 & 4.31 & 0.00 \\
\hline Width & 0.03 & 0.01 & 4.82 & 0.00 \\
\hline Width $\times$ Mature & -0.06 & 0.03 & -2.12 & 0.03 \\
\hline Temp $\times$ Year & -2.80 & 0.66 & -4.25 & 0.00 \\
\hline \multirow[t]{2}{*}{ Parameter } & \multirow[t]{2}{*}{ Odds ratio } & \multicolumn{3}{|c|}{$-95.0 \% \mathrm{CI}-$} \\
\hline & & Upper & & Lower \\
\hline Shell & 9.64 & 31.76 & & 2.92 \\
\hline Mature & 7.00 & 182.14 & & 0.27 \\
\hline Year & 0.19 & 0.64 & & 0.06 \\
\hline Temp & 2.67 & 4.17 & & 1.71 \\
\hline Width & 1.03 & 1.04 & & 1.02 \\
\hline Width $\times$ Mature & 0.94 & 1.00 & & 0.89 \\
\hline Temp $\times$ Year & 0.06 & 0.22 & & 0.02 \\
\hline \multicolumn{5}{|c|}{$\begin{array}{l}\text { Log likelihood (LL): }-982.85 ; \text { LL of constants only model }= \\
\text { LL }(0)=-1088.59 ; 2 \times[L L(N)-L L(0)]=211.49 \text { with } 7 \mathrm{df} \text { chi- } \\
\text { square p-value }=0.00 ; \text { McFadden's rho-squared =0.10; } \\
n=344 \text { infected crabs, } 2826 \text { uninfected crabs }\end{array}$} \\
\hline
\end{tabular}

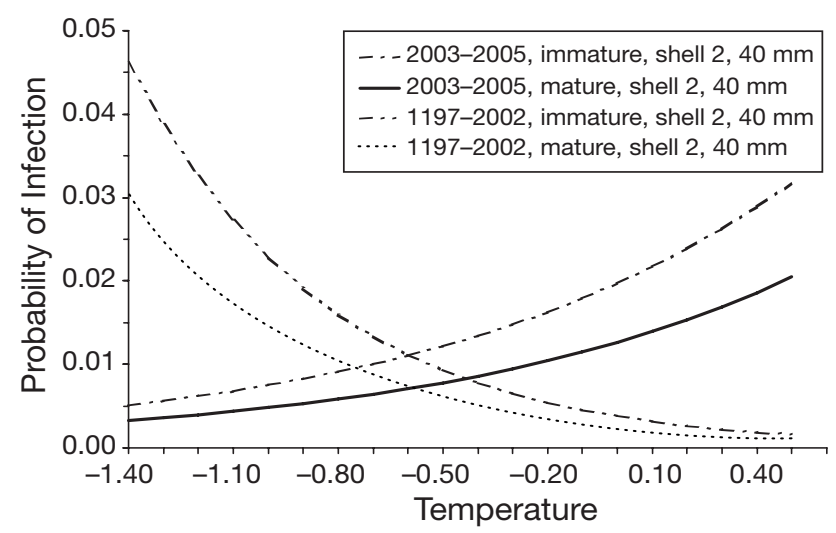

Fig. 10. Chionoecetes opilio. Estimated probabilities of infection with bitter crab disease (BCD) in relation to temperature for female snow crabs trawled from Conception Bay over 2 temporal periods. Model and regression equations are given in Table 2. Different molt conditions (Shell Condition 2 vs. other shell conditions) and maturity (immature vs. mature) have widely different probabilities of infection 

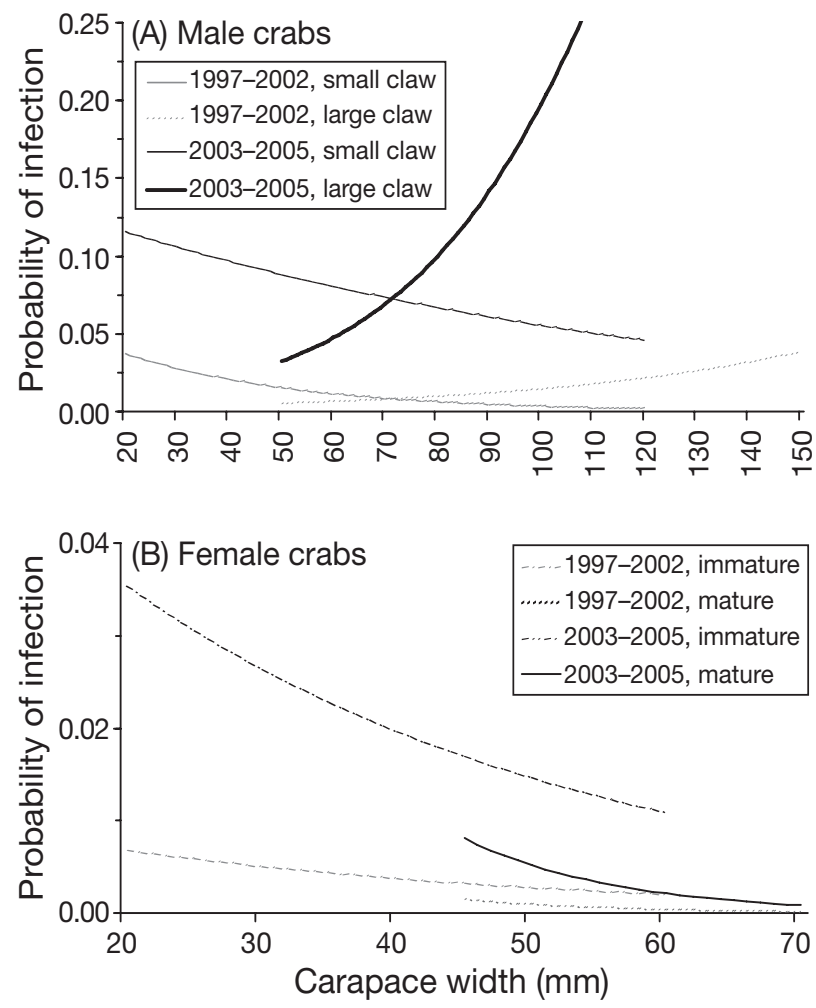

Fig. 11. Chionoecetes opilio. Estimated probabilities of infection with bitter crab disease (BCD) by carapace width for (A) small- and large-clawed males and (B) immature and mature female snow crabs trawled from Conception Bay over 2 different temporal periods, with temperature held at $0^{\circ} \mathrm{C}$ and Shell Condition 2. Note the shift in the slopes for the large-claw males in 2003 to 2005. Regression equations are given in Tables $1 \& 2$

claw males), and for crabs in other shell conditions. In summary, a juvenile female crab in Shell Condition 2 had the greatest risk of disease prior to 2003 (Table 3), whereas a legal-sized, large-clawed male in Shell Condition 2 had similar or greater risk of disease in 2003 to 2005.

\section{DISCUSSION}

We have documented an underlying shift in the factors that may be responsible for outbreaks of BCD in snow crabs Chionoecetes opilio from Conception Bay, Newfoundland. Increased molting activity, likely triggered by rising bottom temperatures, led to an increase in the number of susceptible prerecruit smallclawed juveniles and adolescent small-clawed males in the population from 2002 to 2005. Because transmission of BCD is associated with molting (Shell Conditions 1 and 2) (Shields et al. 2005), the prolonged increase in molting activity from 2002 through 2005 led to a profusion of susceptible hosts, fueling the epidemic over time (see Fig. 7). Prior to 2001, the proportion of juvenile males and females that had molted recently (Shell Condition 2) remained high (40 to $70 \%$ ), and likely sustained the epidemic in juveniles and females. In 2001, molting activity was significantly reduced in the crab population (a condition known as skip molting — see below). This likely caused the 1999 to 2000 outbreak to subside due to a substantial decrease in the number of susceptible hosts, and may have helped to synchronize molting activity in 2002, contributing to the increase in molting activity in conjunction with rising temperatures. Such enhanced molting events have been documented in the Tanner crab Chionoecetes bairdi, which is a close congener of the snow crab (Stone 1999). Further, sporulation of Hematodinium in the Norway lobster Nephrops norvegicus is timed with molting, and annual molting patterns may determine the likelihood of an outbreak in a particular year (Stentiford et al. 2001). In years when molting is primarily synchronous, prevalence of disease increases; in years when molting is asynchronous, lower prevalence occurs.

Molting frequency and, possibly, molt increment are positively correlated with temperature in the Crustacea (e.g. Conan 1985, Fisher 1999), and snow crabs appear to be no exception. However, snow crabs can skip an annual molt, even at small sizes (Benhalima et al. 1998, Hébert et al. 2002), presumably when physiologically stressed by either environmental or densitydependent factors. Accordingly, in 1985, the snow crab fishery off the Avalon Peninsula, Newfoundland, experienced a collapse in landings that was associated with a temperature decline from -0.6 to $-1.4^{\circ} \mathrm{C}$ starting in 1982 (Taylor et al. 1993). The lower temperature apparently interrupted the molting activity of the snow crabs causing them to skip molting during cold years. While circumstantial, the converse of warmer temperatures increasing molting activity also has been shown in snow crabs (Taylor et al. 1993). Interestingly, even though temperature was strongly correlated with BCD in females, it showed no statistical interaction with shell condition, which it did in males. Prevalence values between trawled females were not significantly different during the height of each outbreak (2000 and 2005). Nonetheless, in our study, increasing water temperatures were correlated with increasing molting activity in small-clawed males molting into largeclawed males, and molting was strongly correlated with BCD.

How Hematodinium infections in snow crabs respond to temperature increases is at present unknown. Low temperatures and salinities limit the proliferation of Hematodinium sp. in blue crabs Callinectes sapidus (Messick et al. 1999). However, the parasite in boreal 
snow crabs is cold-adapted and has a very different biology than the species infecting blue crabs (see Stentiford \& Shields 2005, for review).

With the shift in BCD infections into legal-sized male crabs, the 2003 to 2005 outbreak had a direct economic impact on the fishery. Conception Bay is within the 3L Fishing Division of the North Atlantic Fisheries Organization. In 2005, snow crab landings totaled 43900 metric tons (t) in Newfoundland, with $24900 \mathrm{t}$ (56.7\%) from the 3L division (DFO 2006a). The quota for Conception Bay was $1100 \mathrm{t}$ in 2005, down from $1450 \mathrm{t}$ in 2003 (DFO 2006b). In the 2005 fall survey in Conception Bay, $34.6 \%$ of the legal-sized, large-clawed males and $14.9 \%$ of the legal-sized, small-clawed males had BCD (Fig. 3), and legal-sized, large-clawed males represented $75.4 \%$ of the legal catch in our 2005 trap data. Assuming that infected crabs in June, at the start of the fishery, were identifiable or in a similar stage of infection to those in October (but see below) at the time of the survey, then an estimated $327.1 \mathrm{t}$ of crab, worth Can\$1.04 million in ex-vessel price (at Can\$3190 $\mathrm{t}^{-1}$ ), was discarded by the fishing industry in Conception Bay. However, broad estimates of monetary impact are not feasible for 2 reasons. Prevalence can vary between adjacent bays, with epidemics occurring in one and not another (Shields et al. 2005), and infections may not be obvious in the early part of the fishing season (Love et al. 1993, D. M. Taylor pers. obs.). Infected crabs may not be identifiable as such in June, the peak time of fishing activity. However, the crabs that were obviously infected in October would be lost to the following year's fishery. In the 2000 outbreak, direct losses due to BCD were difficult to estimate, because the disease was most prevalent in under-sized males and females (Shields et al. 2005).

Mortalities in the small females and juvenile males may affect future recruitment and economic returns in this fishery. The change in the size-frequency distributions for females and males during the 2003 to 2005 outbreak may reflect increased mortality in the smaller infected sizes or it may reflect vagaries in sampling over 3 versus 6 yr. Given that infected Tanner and snow crab hosts die from their infections (Meyers et al. 1987, Love et al. 1993, Shields et al. 2005), we speculate that an increase in mortality during this second, larger outbreak may have been responsible for the decrease in the more heavily infected smaller size classes. The mortality was not as evident in the larger size classes, presumably because the outbreak had only recently spread into the legal, large-clawed males.

Recent epidemics of disease agents in marine animals have been attributed to stress brought about by climatic variability related to global warming (Epstein et al. 1998, Harvell et al. 1999). However, there is some question as to whether these epidemics are truly emergent phenomena or simply the result of increased scientific investigation (Harvell et al. 2002, Ward \& Lafferty 2004). Our monitoring of snow crabs has shown that epidemics of $\mathrm{BCD}$ are indeed emerging phenomena, with 10-fold increases in prevalence occurring over the short period since its initial discovery in the fishery (Fig. 2; see Taylor \& Khan 1995, Shields et al. 2005). In snow crabs, rising temperatures

Table 3. Chionoecetes opilio. Prevalence (\% bitter crab disease, BCD) and prevalence ratios (PR) for single biotic risk factors in relation to BCD from trawled snow crabs for 1997 to 2002 and 2003 to 2005. Prevalence ratio is given as the larger determinant as the numerator over the smaller determinant as the denominator. Odds ratios for carapace widths (CW) are given in Tables 2 \& 3

\begin{tabular}{|c|c|c|c|c|c|c|c|}
\hline $\begin{array}{l}\text { Biotic } \\
\text { determinants }\end{array}$ & & $\begin{array}{c}1997-2002 \\
\% \text { BCD }\end{array}$ & $\begin{array}{c}\mathrm{PR} \\
(\ln \mathrm{PR}+\mathrm{SE})\end{array}$ & $\mathrm{N}$ & $\begin{array}{c}2003-2005 \\
\% \text { BCD }\end{array}$ & $\begin{array}{c}\mathrm{PR} \\
(\ln \mathrm{PR}+\mathrm{SE})\end{array}$ & $\mathrm{N}$ \\
\hline Sex & $\begin{array}{l}\text { Male } \\
\text { Female }\end{array}$ & $\begin{array}{c}3.20 \\
11.25\end{array}$ & $\begin{array}{c}3.52 \\
(1.26+0.07)\end{array}$ & $\begin{array}{c}14728 \\
3421\end{array}$ & $\begin{array}{l}6.12 \\
7.90\end{array}$ & $\begin{array}{c}1.32 \\
(0.27+0.10)\end{array}$ & $\begin{array}{l}7401 \\
1760\end{array}$ \\
\hline Maturity female & $\begin{array}{l}\text { Juvenile } \\
\text { Adult }\end{array}$ & $\begin{array}{c}14.79 \\
2.62\end{array}$ & $\begin{array}{c}5.24 \\
(1.73+0.21)\end{array}$ & $\begin{array}{c}2427 \\
993\end{array}$ & $\begin{array}{c}10.72 \\
4.13\end{array}$ & $\begin{array}{c}2.56 \\
(0.95+0.21)\end{array}$ & $\begin{array}{c}1007 \\
751\end{array}$ \\
\hline Male claw morph & $\begin{array}{l}\text { Small claw } \\
\text { Large claw }\end{array}$ & $\begin{array}{l}5.31 \\
0.82\end{array}$ & $\begin{array}{c}6.48 \\
(1.87+0.18)\end{array}$ & $\begin{array}{l}7625 \\
4026\end{array}$ & $\begin{array}{l}5.56 \\
9.86\end{array}$ & $\begin{array}{c}1.77 \\
(0.57+0.10)\end{array}$ & $\begin{array}{l}4704 \\
1815\end{array}$ \\
\hline Legal size & $\begin{array}{l}<95 \mathrm{~mm} \mathrm{CW} \\
>95 \mathrm{~mm} \mathrm{CW}\end{array}$ & $\begin{array}{l}3.88 \\
0.70\end{array}$ & $\begin{array}{c}5.51 \\
(1.71+0.22)\end{array}$ & $\begin{array}{l}11604 \\
3124\end{array}$ & $\begin{array}{c}4.34 \\
12.03\end{array}$ & $\begin{array}{c}2.77 \\
(1.02+0.10)\end{array}$ & $\begin{array}{l}5689 \\
1712\end{array}$ \\
\hline Shell condition & $\begin{array}{l}\text { Other } \\
\text { Condition } 2\end{array}$ & $\begin{array}{c}0.26 \\
6.605\end{array}$ & $\begin{array}{c}25.40 \\
(3.24+0.27)\end{array}$ & $\begin{array}{l}5386 \\
12765\end{array}$ & $\begin{array}{l}2.69 \\
7.72\end{array}$ & $\begin{array}{c}2.88 \\
(1.05+0.15)\end{array}$ & $\begin{array}{l}2115 \\
7046\end{array}$ \\
\hline
\end{tabular}


stimulated molting activity in the population, thereby increasing the abundance of susceptible hosts. The increased molting activity occurred over $3 \mathrm{yr}$, enhancing the amplification of the parasite to epidemic levels. Furthermore, outbreaks of Hematodinium spp. are associated with enclosed or entrained water masses, which apparently facilitate transmission (see Stentiford \& Shields 2005 for review); and BCD is no exception, with increased prevalence associated with the deeper, more restricted portions of Conception Bay (Shields et al. 2005), a bay with weak circulation and slow exchange (DeYoung \& Sanderson 1995).

Climatic variability associated with global warming may cause fragmentation or reduction of ecosystems changes that can force the concentration of hosts and pathogens (Holmes 1996) — and such may be occurring here. Snow crabs normally live at -1.4 to $<3^{\circ} \mathrm{C}$ (Powles 1968, Brêthes et al. 1987, Dionne et al. 2003), and, prior to 2004, the mean fall temperature in Conception Bay was $-0.85 \pm 0.18^{\circ} \mathrm{C}(\mathrm{SD})$; thus, the nearly $1^{\circ} \mathrm{C}$ change in 2004 to 2005 was outside what these crabs normally experience at this time. However, other than increased molting activity and the relationship with BCD, we do not know how rising temperature may have affected these snow crabs or the pathogen. In other marine and aquatic systems, rising temperatures can lead to increased rates of disease transmission, exacerbate the severity of disease, and enhance susceptibility to opportunistic infections in aquatic and marine hosts (Esch et al. 1975, Sousa \& Gleason 1989, Lavigne \& Schmitz 1990, Dobson \& Carper 1992, Lloyd 1995, Marcogliese 2001). Given the association between temperature, molting, and outbreaks of $\mathrm{BCD}$, we speculate that increasing local ocean temperatures, possibly associated with global warming, will prolong and enhance the transmission and spread of epidemics of the parasite into additional fishing areas.

Acknowledgements. We thank Hamish Small, Dave Gauthier, Caiwen $\mathrm{Li}$ and Kersten Wheeler for their critiques of the manuscript. We are indebted to the captains and crews of the CCGS 'Shamook' for their invaluable assistance in collecting snow crabs and for their shipboard professionalism to visiting scientists. The technical staff of the DFO Shellfish section provided able field and technical contributions to this project. Travel for J.D.S. was supported in part by the DFO and in part by the VIMS. This is Contribution No. 2792 from the Virginia Institute of Marine Science.

\section{LITERATURE CITED}

Benhalima K, Moriyasu M, Hébert M (1998) A technique for identifying the early-premolt stage in the male snow crab Chionoecetes opilio (Brachyura: Majidae) in Baie des Chaleurs, southern Gulf of St. Lawrence. Can J Zool 76(4): 609-617

Bower SM, Meyer GR, Phillips A, Workman G, Clark D (2003) New host and range extension of bitter crab syndrome in
Chionoecetes spp. caused by Hematodinium sp. Bull Eur Assoc Fish Pathol 23:86-91

Brêthes JCF, Coulombe F, Lafleur PE, Bouchard R (1987) Habitat and spatial distribution of early benthic stages of the snow crab Chionoecetes opilio O. Fabricius off the north shore of the Gulf of St. Lawrence. J Crustac Biol 7: 667-681

Comeau M, Conan GY (1992) Morphometry and gonad maturity of male snow crab, Chionoecetes opilio. Can J Fish Aquat Sci 49:2460-2468

Comeau M, Starr M, Conan GY, Robichaud G, Therriault JC (1999) Fecundity and duration of egg incubation for multiparous female snow crabs (Chionoecetes opilio) in the fjord of Bonne Bay, Newfoundland. Can J Fish Aquat Sci 56:1088-2095

Conan GY (1985) Periodicity and phasing of molting. In: Wenner AM (ed) Crustacean issues, Vol 3. Factors in adult growth. AA Balkema, Rotterdam, p 73-100

Dawe EG (2002) Trends in prevalence of bitter crab disease caused by Hematodinium sp. in snow crab (Chionoecetes opilio) throughout the Newfoundland and Labrador continental shelf. In: Paul AJ, Dawe EG, Elner R, Jamieson GS and 5 others (eds) Crabs in cold water regions: biology, management, and economics. AK-SG-01-01, University of Alaska Sea Grant, Fairbanks, AK, p 385-399

Dawe EG, Taylor DM, Hoenig JM, Warren WG and 5 others (1991) A critical look at the idea of terminal molt in male snow crab (Chionoecetes opilio). Can J Fish Aquat Sci 48: 2266-2275

DeYoung B, Sanderson B (1995) The circulation and hydrography of Conception Bay, Newfoundland. Atmos-Ocean 33:135-162

DFO (Department of Fisheries and Oceans) (2006a) Assessment of Newfoundland and Labrador snow crab. DFO Can Sci Advis Sec Sci Advis Rep 2006/006, DFO, St. Johns, Newfoundland. Available at www.dfo-mpo.gc.ca./ csas/Csas/status/2006/SAR-AS2006_006_E.pdf

DFO (Departement of Fisheries and Oceans) (2006b) Species quota report: snow crab. Statistical Services, DFO, St. Johns, Newfoundland. Available at www.nfl.dfo-mpo. gc.ca./publications/ reports_rapports2.asp

Dionne M, Sainte-Marie B, Bourget E, Gilbert D (2003) Distribution and habitat selection of early benthic stages of snow crab Chionoecetes opilio. Mar Ecol Prog Ser 259: $117-128$

Dobson A, Carper R (1992) Global warming and potential changes in host-parasite and disease-vector relationships. In: Peters RL, Lovejoy TE (eds) Global warming and biological diversity. Yale University Press, New Haven, CT, p 201-217

Eaton WD, Love DC, Botelho C, Meyers TR, Imamura $\mathrm{K}$, Koeneman T (1991) Preliminary results on the seasonality and life cycle of the parasitic dinoflagellate causing bitter crab disease in Alaskan Tanner crabs (Chionoecetes bairdi). J Invertebr Pathol 57:426-434

Ennis GP, Hooper RG, Taylor DM (1988) Functional maturity in small male snow crabs (Chionoecetes opilio). Can J Fish Aquat Sci 45:2106-2109

Ennis GP, Hooper RG, Taylor DM (1990) Changes in composition of snow crab, Chionoecetes opilio, participating in the breeding migration in Bonne Bay, Newfoundland. Can J Fish Aquat Sci 47:2242-2249

Epstein PR, Sherman B, Spanger-Siegfried E, Langston A, Prasad S (1998) Marine ecosystems: emerging diseases as indicators of change. The Center for Health and the Global Environment, Harvard Med School, Boston, MA

Esch GW, Gibbons JW, Bourque JE (1975) An analysis of the 
relationship between stress and parasitism. Am Midl Nat 93:339-353

Fisher MR (1999) Effect of temperature and salinity on size at maturity of female blue crabs. Trans Am Fish Soc 128: 499-506

Harvell CD, Kim K, Burkholder JM, Colwell RR and 9 others (1999) Emerging marine diseases - climate links and anthropogenic factors. Science 285 (3):1505-1510

Harvell CD, Mitchell CE, Ward JR, Altizer S, Dobson AP, Ostfeld RS, Samuel MD (2002) Climate warming and disease risks for terrestrial and marine biota. Science 296: 2158-2162

Hébert M, Benhalima K, Miron G, Moriyasu M (2002) Moulting and growth of male snow crab, Chionoecetes opilio (O. Fabricius, 1788) (Decapoda, Majidae), in the southern Gulf of St. Lawrence. Crustaceana 75:671-702

Holmes JC (1996) Parasites as threats to biodiversity in shrinking ecosystems. Biodivers Conserv 5:975-983

Lavigne DM, Schmitz OJ (1990) Global warming and increasing population densities: a prescription for seal plague. Mar Pollut Bull 21:280-284

Lloyd S (1995) Environmental influences on host immunity. In: Grenfell BT, Dobson AP (eds) Ecology of infectious diseases in natural populations. Cambridge University Press, Cambridge, p 327-361

Love DC, Rice SD, Moles DA, Eaton WD (1993) Seasonal prevalence and intensity of bitter crab dinoflagellate infection and host mortality in Alaskan Tanner crabs Chionoecetes bairdi from Auke Bay, Alaska, USA. Dis Aquat Org 15:1-7

Marcogliese DJ (2001) Implications of climate change for parasitism of animals in the aquatic environment. Can J Zool 79:1331-1352

Messick GA, Jordan SJ, Van Heukelem WF (1999) Salinity and temperature effects on Hematodinium sp. in the blue crab Callinectes sapidus. J Shellfish Res 18:657-662

Meyers TR, Koeneman TM, Botelho C, Short S (1987) Bitter crab disease: a fatal dinoflagellate infection and marketing problem for Alaskan Tanner crabs Chionoecetes bairdi. Dis Aquat Org 3:195-216

Meyers TR, Botelho C, Koeneman TM, Short S, Imamura K (1990) Distribution of bitter crab dinoflagellate syndrome in southeast Alaskan Tanner crabs Chionoecetes bairdi. Dis Aquat Org 9:37-43

Meyers TR, Morado JF, Sparks AK, Bishop GH, Pearson T, Urban D, Jackson D (1996) Distribution of bitter crab syndrome in Tanner crabs (Chionoecetes bairdi, C. opilio) from the Gulf of Alaska and Bering Sea. Dis Aquat Org 26: 221-227

Pestal GP, Taylor DM, Hoenig JM, Shields JD, Pickavance R

Editorial responsibility: Julie Bebak, Auburn, Alabama, USA
(2003) Monitoring the presence of the parasitic dinoflagellate Hematodinium sp. in snow crabs Chionoecetes opilio from Conception Bay, Newfoundland. Dis Aquat Org 53: $67-75$

Powles H (1968) Distribution and biology of the spider crab, Chionoecetes opilio in Magdalen Shallows, Gulf of St. Lawrence. Fish Res Board Can Manuscript Rep 997

Sainte Marie B (1993) Reproductive cycle and fecundity of primiparous and multiparous female snow crab, Chionoecetes opilio, in the northwest Gulf of St. Lawrence. Can J Fish Aquat Sci 50:2147-2156

Shields JD (1994) The parasitic dinoflagellates of marine Crustacea. Annu Rev Fish Dis 4:241-271

Shields JD, Taylor DM, Sutton SG, O'Keefe PG, Ings D, Pardy AL (2005) Epidemiology of bitter crab disease (Hematodinium sp.) in snow crabs Chionoecetes opilio from Newfoundland, Canada. Dis Aquat Org 64:253-264

Sousa WP, Gleason M (1989) Does parasitic infection compromise host survival under extreme environmental conditions? The case for Cerithidea californica (Gastropoda: Prosobranchia). Oecologia 80:456-464

Stentiford GD, Shields JD (2005) A review of the parasitic dinoflagellates Hematodinium species and Hematodinium-like infections in marine crustaceans. Dis Aquat Org 66:47-70

Stentiford GD, Neil DM, Atkinson RJA (2001) The relationship of Hematodinium infection prevalence in a Scottish Nephrops norvegicus population to seasonality, moulting and sex. ICES J Mar Sci 58:814-823

Stone RP (1999) Mass molting of Tanner crabs Chionoecetes bairdi in a southeast Alaska estuary. Alsk Fish Res Bull 6: $19-28$

Taylor DM, Khan RA (1995) Observations on the occurrence of Hematodinium sp. (Dinoflagellata: Syndinidae), the causative agent of bitter crab disease in Newfoundland snow crab (Chionoecetes opilio). J Invertebr Pathol 65: 283-288

Taylor DM, Marshall GW, O'Keefe PG (1989) Shell hardening in snow crab tagged in soft-shelled condition. N Am J Fish Manag 9:504-508

Taylor DM, O'Keefe PG, Fitzpatrick C (1993) A snow crab, Chionoecetes opilio (Decapoda, Majidae), fishery collapse in Newfoundland. Fish Bull (Wash DC) 92:412-419

Thrusfield M (1995) Veterinary epidemiology, 2nd edn. Blackwell Science, Oxford

Ward RJ, Lafferty KD (2004) The elusive baseline of marine disease: Are diseases in ocean ecosystems increasing? PloS Biol 2:542-547

Wilkinson L (1997) SYSTAT 7.0: new statistics. SPSS, Chicago, IL

Submitted: July 5, 2006; Accepted: May 21, 2007

Proofs received from author(s): July 16, 2007 